\title{
Peran Pemuda Karang Taruna Bunga Bakung Dalam Pembangunan Di Desa Metun Sajau Kecamatan Tanjung Palas Timur Kabupaten Bulungan Kalimantan Utara
}

\author{
K. Rapiandi Isak Merang ${ }^{1}$ \\ isakrapiandi@yahoo.co.id \\ Robert $^{2}$ \\ robertusat@gmail.com \\ ${ }^{1,2}$ Universitas Kaltara
}

\begin{abstract}
ABSTRAK
Tujuan penelitian untuk mengetahui peranan pemuda Karang Taruna Bunga Bakung dalam pembangunan di Desa Metun Sajau dan untuk mengetahui kendala-kendala yang dihadapi pemuda Karang Taruna Bunga Bakung dalam pembangunan di Desa Metun Sajau.Jenis penelitian deskriptif kualitatif. Informan yaitu pengurus Karang Taruna, anggota Karang Taruna Bunga Bakung, Sekertaris Desa, pengurus Adat Desa Metun Sajau, dan Tokoh Masyarakat Desa Metun Sajau. Teknik pengumpulan data yaituobservasi, wawancara, dan dokumentasi. Teknik analisis data yaitupengumpulan data, reduksi data, penyajian data, dan penarikan kesimpulan. Hasil penelitian menunjukan peran pemuda Karang Taruna Bunga Bakung dalam pembangunan di Desa Metun Sajau dapat dilihat dari pembangunan fisik diantaranya pembangunan sarana jalan, pembangunan rumah adat, pembangunan tribun lapangan, dan pembangunan sarana olahraga. Peran dalam pembangunan non fisik diantaranya menyampaikan pendapat saat rapat desa, menjaga keamanan dan ketertiban, dan pelestarian kesenian daerah.Kendala-kendala yang dihadapi Karang Taruna Bunga Bakung dalam pembangunan di Desa Metun Sajauyaitu keterbatasan dana, kurangnya sarana dan prasarana, kurangnya komunikasi dan koordinasi dari pimpinan, sibuk karena pekerjaan, kurang tegas pimpinan organisasi Karang Taruna, kurangnya kesadaran masyarakat terhadap peran dan fungsi Karang Taruna, dan kurangnya perhatian pemerintah desa.
\end{abstract}

Kata Kunci: Peran Karang Taruna, Pembangunan, Desa

\begin{abstract}
The aim of the study was to determine the youth role of the Karang Bakuna Youth in the development of Metun Sajau Village and to find out the obstacles faced by the young people of the Karang Bakuna Bunga Bakung in the development of Metun Sajau Village. Type of qualitative descriptive research. The informants were the Karang Taruna management, members of the Bunga Bakung Youth Organization, the Village Secretary, the Indigenous Village administrators of Metun Sajau Village, and the People of the Metun Sajau Village Community. Data collection techniques are observation, interviews, and documentation. Data analysis techniques are data collection, data reduction, data presentation, and conclusion drawing. The results of the study show that the role of the youth of the Bunga Bakung Youth Organization in the development of Metun Sajau Village can be seen from the physical development including construction of road facilities, construction of traditional houses, construction of field stands, and construction of sports facilities. Roles in non-physical development include expressing opinions in village meetings, maintaining security and order, and preserving regional arts. The constraints faced by the Flower Village Youth Organization in the development in Metun Sajau Village are limited funding, lack of facilities and infrastructure, lack of communication and coordination from the leadership, busy due to work, less assertive leadership of the Karang Taruna organization, lack of awareness of the village's role and function Taruna, and the lack of attention of the village government.
\end{abstract}

Keywords: Role of Youth, Development, Village 
PENDAHULUAN

Karang Taruna merupakan organisasi kepemudaan di Indonesia. Karang Taruna merupakan organisasi sosial wadah pengembangan generasi muda yang tumbuh dan berkembang atas dasar kesadaran dan tanggung jawab sosial dari, oleh dan untuk masyarakat terutama generasi muda diwilayah Desa/Kelurahan dengan fungsi untuk mensejahterakan kehidupan masyarakat. Karang Taruna bertujuan sebagai wadah untuk mengembangkan potensi yang dimiliki generasi muda.

Keberadaan Karang Tauruna seyogianya dapat memberikan perubahan bagi suatu desa karena pemuda atau Karang Taruna sebagai tulang punggung sebuah desa yang sangat diharapkan dapt memberikan kontribusi bagi pembangunan. Karang Taruna sebagai tulang punggung harus mampu memberikan dan menunjukan perannya melalui kegiatan-kegiatan sosial seperti terlibat dalam kegiatan kerja bakti (gotongroyong), ikut terlibat dalam menyampaikan pendapat dalam rapat desa, dan ikut mengawasi kegiatan pembangunan yang dilaksankan.

Dari pengamatan bahwa setiap desa hampir memiliki organisasi Karang Taruna namun kenyataan yang dihadpi bahwa organisasi tersebut tidak berjalan dengan baik, sehingga peran dari karang Taruna tidak dirasakan oleh masyarakat. Peran Karang Tauruna tidak berjalan dengan baik disebabkanperbedaan pendapat dalam menjalankan organisasi, pekerjaan yang banyak, kondisi sosial budaya, dan latar belakang pendidikan rendah. Selain dari pada itu, kurangnya pemahaman pemuda Karang Taruna di desa dalam menjalankan organisasi sehingga berdampak pada pelaksanaan, eksistensi, dan tujuan yang tercantum dalam visi dan misi.

Sebagaimana yang dilakukan pemuda Karang Taruna Bunga Bakung di Desa Metun Sajau Kecamatan Tanjung Palas Timu Kabupaten Bulungan, Karang Taruna ini mempunyai program-program kerja yang berorientasi pada pembangunan dan kesejahteraan masyarakat. Mengingat bahwa Desa Metun Sajau merupakan desa Wisata, tentunya sangat membutukan pembangunan sebagai fasilitas dalam meningkatkan kesejahteraan masyarakat. Peran pemuda Karang Taruna diharapkan dapat dirasakan oleh masyarakat. Oleh karena itu, Karang Tarunasebagai tulang punggung kemajuan desa harus mampu berperan secara maksimal untuk kemajuan desa Metun Sajau.

Melihat begitu pentingnya peran karang taruna dalam pembangunan di desa sehingga mendorong penulis untuk melakukan penelitian dengan judul "Peran 
pemuda Karang Taruna Bunga Bakung dalam pembangunan di Desa Metun Sajau Kecamatan Tanjung Palas TimurKabupaten Bulungan".

\section{LANDASAN TEORI}

\section{A. Pengertian Peranan}

Dalam kehidupan masyarakat setiap individu mempunyai peranan-peranan yang berbeda-beda. Peranan-peranan yang dilakukan tersebut selalu di harapkan dalam kehidupan masyarakat. Seorang individu senantiasa berhubungan dengan pihak lain. Peranan individu dapat dilihat dalam hubungan dalam kelompok. Sebagaimana manusia satu sama lain mengadakan interaksi dan mengadakan pengaruh timbal balik, demikian pula kelompok dan lembaga-lembaga sosial mengadakan interaksi satu sama lain dan mempengaruhi lingkungannya. Interaksi dalam kelompok tersebut dituntut adanya peranan dari masing-masing individu yang saling bekerjasama untuk menyelesaikan masalah.

Adapun pengertian peranan dalam masyarakat adalah sebagai berikut, "Peranan adalah konsekuensi atau akibat kedudukan atau status seseorang dalam menjalankan hak dan kewajiban. Peranan mencakup kewajiban dan hak yang bertalian dengan kedudukan" (Nasution, 2004). Sedangkan menurut Soerjono Soekanto "peranan (role) merupakan aspek dinamis dari kedudukan (status). Apabila seseorang melaksanakan hak dan kewajibannya sesuai dengan kedudukannya, berarti dia menjalankan suatu peranan". (Soerjono Soekanto, 2007).

Dari dua pengertian peranan di atas dapat disimpulkan bahwa peranan adalah perilaku dari status kedudukan untuk menjalankan apa yang menjadi hak dan kewajibannya. Sedangkan status itu merupakan suatu posisi atau kedudukan yang melekat pada diri seseorang dalam kelompok yang berperanan dapat menjalankan pekerjaannya. Status dan peranan merupakan dua aspek yang bersama-sama keberadaannya dapat ditunjukkan dengan perilaku yang bermanfaat bagi dirinya sendiri maupun bagi orang lain ataupun kelompok masyarakat. Status adalah seperangkat hak dan kewajiban, sedangkan peran adalah tindakan dari wujud perangkat kewajiban dan hak-hak. Di dalam masyarakat kita mempunyai status dan kedudukan sesuai dengan peranan sosial yang mesti dimainkan. Setiap orang menduduki status yang diharapkan dapat berperilaku mengikuti pola yang dibenarkan sesuai dengan peranannya.

B. Pengertian Pemuda

Menurut Agoes Soejanto (2005: 161 162) masa pemuda adalah masa yang 
menentukan, menentukan hari depannya, menentukan kehidupannya. menentukan kehidupan keluarganya, bahkan menentukan nasib bangsa dan negaranya. Bukankah sering kita dengar dari para pemimpin bahwa nasib negara dan bangsa ada di tangan para pemudanya, sebagai calon pengganti angkatan tua. Karena itu, orang tua yung memahami masa pemuda anak-anaknya, ia akan merasakan kepuasan di dalam tugas hidupnya. Pemuda yang memahami dirinya adalah pemuda yang dapat berharap akan kehidupan yang bahagia.

Dibawah ini dijabarkan kelompokkelompok yang dapat di pergunakan sebagai pegangan di dalam pembinaan dan pengembangan anak-anak pada khususnya dan pada generasi muda pada umumnya.

Menurut Agoes Soejanto (2005: 160) dalam psikologi perkembangan, jika dilihat dari biologis, terdapat istilah-istilah bayi, anak, remaja, pemuda dan dewasa digolongkan sebagai berikut:
1) Bayi : 0 - 2 tahun
2) Kanak-kanak :3-5 tahun
3) Masa anak (sekolah) : 6 - 12 tahun
4) Pemuda : :13-16/22 tahun
5) Dewasa : $23-45$ tahun
keatas, dan 17 sampai 40

Dari pengertian pemuda di atas dapat ditarik kesimpulan bahwa pemuda adalah penduduk berusia muda, yaitu berusia 13 sampai 22 tahun yang dibina dan diarahkan peranannya sehingga dapat berkontribusi dalam masyarakat. Pemuda merupakan satu identitas yang potensial sebagai penerus cita-cita perjuangan bangsa. Maju tidaknya suatu bangsa ada ditangan pemuda, oleh karena itu pembinaan pemuda harus dilakukan oleh pemerintah.

C. Karang Taruna

Karang Taruna adalah organisasi kepemudaan di Indonesia. Karang Taruna merupakan organisasi sosial wadah pengembangan generasi muda yang tumbuh dan berkembang atas dasar kesadaran dan tanggung jawab sosial dari, oleh dan untuk masyarakat terutama generasi muda diwilayah Desa/Kelurahan dengan fungsi untuk mensejahterakan kehidupan masyarakat. Karang Taruna bertujuan sebagai wadah untuk mengembangkan potensi yang dimiliki generasi muda.

Peraturan Menteri Sosial Republik Indonesia Nomor: 77/Huk/2010 Tentang Pedoman Dasar Karang Taruna Pasal 1, dalam Peraturan ini yang dimaksud dengan:

a. Karang Taruna adalah organisasi sosial kemasyarakatan sebagai wadah dan sarana pengembangan setiap anggota masyarakat yang tumbuh dan berkembang atas dasar kesadaran dan tanggung jawab sosial dari, oleh dan 
untuk masyarakat terutama generasimuda di wilayah desa/ kelurahan terutama bergerak dibidang usaha kesejahteraan sosial.

b. Anggota Karang Taruna yang selanjutnya disebut Warga Karang Taruna adalah setiap anggotamasyarakat yang berusia 13 (tiga belas) tahun sampai dengan 45 (empat puluh lima) tahunyang berada di desa/kelurahan.

c. Forum Pengurus Karang Taruna adalah wadah atau sarana kerjasama Pengurus Karang Taruna dalam melakukan komunikasi, informasi, konsultasi, koordinasi, konsolidasi dan kolaborasi, sebagai jejaring sosial Pengurus Karang Taruna Kecamatan, Kabupaten, Provinsi dan Nasional.

d. Desa atau yang disebut dengan nama lain, selanjutnya disebut desa adalah kesatuan masyarakat hukum yang memiliki batas-batas wilayah yang berwenang untuk mengatur dan mengurus kepentingan masyarakat setempat, berdasarkan asal-usul dan adat istiadat setempat yang diakui dan dihormati dalam sistem Pemerintahan Negara Kesatuan RepublikIndonesia.

e. Majelis Pertimbangan Karang Taruna (MPKT) adalah wadah berhimpun mantan pengurus Karang Taruna dan tokoh masyarakat lain yang berfungsi memberikan nasehat, mengarahkan, saran dan/atau pertimbangan demi kemajuan Karang Taruna.

f. Kesejahteraan Sosial adalah kondisi terpenuhinya kebutuhan material, spiritual, dan sosial warga negara agar dapat hidup layak dan mampu mengembangkan diri sehingga dapat melaksanakan fungsi sosialnya.

g. Penyelenggaraan Kesejahteraan Sosial adalah upaya yang terarah, terpadu, dan berkelanjutan yang dilakukan Pemerintah, pemerintah daerah, dan masyarakat dalam bentuk pelayanan.

D. Pembangunan

Pada hakekatnya pembangunan itu dilaksanakan oleh pemerintah bersamasama rakyat dengan tujuan memberikan kemakmuran dan kesejahteraan pada masyarakat. Pembangunan adalah suatu usaha yang dilakukan, dalam mengadakan perubahan-perubahan atau perkembangan menuju kearah yang lebih baik dari sebelumnya. Pelaksanaan pembangunan tersebut dilaksanakan bersama-sama oleh pemerintah dan masyarakat sesuai dengan pokok-pokok pembangunan, dimana pembangunan harus dapat memberikan perubahan hidup bagi masyarakat menuju suatu kemakmuran dan kesejahteraan bagi masyarakat.

Dikatakan oleh Susanto, (dalam Lendriyono, 2007) bahwa proses 
pembangunan yang dilaksanakan oleh suatu negara akan berdampak pada terjadinya perubahan sosial masyarakat.

$$
\text { Menurut Effendi }
$$

Pembangunan adalah suatu upaya untuk meningkatkan segenap sumber daya yang dilakukan secara berencana dan berkelanjutan dengan prinsip daya guna dan hasil guna yang merata dan berkeadilan.

Menurut Mizra (dalam Khairuddin, 2000) pembangunan pada dasarnya adalah usaha manusia dan untuk memahami pembangunan tersebut dibutuhkan usaha-usaha yang terpadu dari seluruh sistem pengetahuan, baik fisik, biologis, sosial maupun tentang manusia.

\section{E. Konsep Pembangunan Desa}

Konsep pembangunan biasanya melekat dalam konteks kajian suatu perubahan, pembangunan disini diartikan sebagai bentuk perubahan yang sifatnya direncanakan; setiap orang atau kelompok orang tentu akan mengharapkan perubahan yang mempunyai bentuk lebih baik bahkan sempurna dari keadaan yang sebelumnya; untuk mewujudkan harapan ini tentu harus memerlukan suatu perencanaan. Pembangunan secara berencana lebih dirasakan sebagai suatu usaha yang lebih rasional dan teratur bagi pembangunan masyarakat yang belum atau baru berkembang. (Subandi: 2011:9-11).

Berbagai sudut pandang dapat digunakan untuk menelaah pembangunan pedesaan. Menurut haeruman (1997), ada dua sisi pandang untuk menelaah pedesaan Fauzi Kurniawan (2016),yaitu: Pembangunan pedesaan dipandang sebagai suatu proses alamiah yang bertumpu pada potensi yang dimiliki dan kemampuan masyarakat Desa itu sendiri. Pendekatan ini meminimalkan campur tangan dari luar sehingga perubahan yang diharapkan berlangsung dalam rentang waktu yang panjang.

Sisi yang lain, memandang bahwa pembangunan pedesaan sebagai suatu interaksi antar potensi yang dimiliki oleh masyaraktDesadan dorongan dari luar untuk mempercepat pembangunan pedesaan.

a. Pembangunan Desa adalah proses kegiatan pembangunan yang berlangsung di Desa yang mencakup seluruh aspek kehidupan dan penghidupan masyarakat. Menurut Peraturan Pemerintah Republik Indonesia Nomer: 72 tahun 2005 Tentang Desa sebagaimana dimaksud pada ayat (2) bahwa perencanaan pembangunan Desa disusun secara partisipatif oleh pemerintahan Desa sesuai dengan kewenangannya dan 
menurut tayat (3) bahwa dalam menyusun perencanaan pembangunan Desa wajib melibatkan lembaga kemasyarakatan Desa.

Menurut Marbun (2002) bahwa pembangunan desa adalah seluruh kegiatan yang berlangsung di pedesaan dan meliputi seluruh aspek kehidupan masyarakat, dilaksanakan secara terpadu dengan mengembangkan swadaya gotongroyong masyarakat. Pembangunan desa diarahkan untuk memanfaatkan secara optimal potensi sumber daya alam, dan mengembangkan sumber daya manusianya dengan meningkatkan kualitas hidup, meningkatkan keterampilan, meningkatkan prakarsa, dengan mendapatkan bimbingan dan bantuan dari aparatur pemerintah, sesuai dengan bidang tugasnya masing-masing.

\section{METODE PENELITIAN}

Jenis penelitian yang digunakan dalam penelitian ini adalah deskriptif kualitatif.

\section{A. Lokasi Penelitian}

Penetapan lokasi penelitian sangat penting dalam penelitian dan berdasarkan judul penelitian maka, penelitian dilaksanakan di Desa Metun Sajau Kecamatan Tanjung Palas Timur Kabupaten Bulungan.
B. Pemilihan Informan

Informan dalam penelitian ini adalah orang yang dianggap mengetahui persis tentang penelitian yang akan diteliti. Bahkan orang yang terlibat langsung dalam kegiatan organisasi karang taruna sehingga dapat memudakan peneliti untuk mendapatkan data yang jelas sesuai dengan rumusan masalah dan focus penelitian.

Adapun infoman dalam penelitian ini sebagai berikut:

1. Pengurus Karang Taruna Bunga Bakung Desa Metun Sajau

2. Anggota Karang Taruna Bunga Bakung Desa Metun Sajau

3. Kepala Desa Metun Sajau/Sekertaris

4. Pengurus Lembaga Adat Desa Metun Sajau

5. Tokoh Masyarakat Desa Metun Sajau Data penunjang atau data sekunder adalah data yang diperoleh melalui sumber informasi antara lain melalui :

1. Dokumen-dokumen.

2. Buku-buku referensi, hasil penelitian dan media massa yang relevan .

C. Teknik Pengumpulan Data

Menurut Sugiyono (2013: 62) "Teknik pengumpulan data merupakan langkah yang paling penting dalam penelitian, karena tujuan utama dari penelitian adalah mendapatkan data".

Dalam penelitian ini penulis menggunakan beberapa teknik untuk mengumpulkan data-data yang diperlukan yaitu :

1. Observasi

Dalam penelitiaan ini, obervasi dilakukan untuk mendapatkan dan mengumpulkan data-data yang valid tentang peranan pemuda Karang Taruna dalam kegiatan pembanunan di Metun Sajau serta untuk melengkapi data primer 
dan data sekunder yang dilakukan baik secara formal maupun non formal.

Berdasarkan keterlibatan penulis dalam mengobservasi, maka observasi yang digunakan yaitu observasi partisipatif. Menurut Sanafiah Faisal (1995) yang di kutip kembali oleh Sugiyono (2013: 64) Observasi partisipatif, dalam observasi ini peneliti terlibat dengan kegiatan sehari-hari orang yang sedang diamati atau yang sedang digunakan sebagai sumber data penelitian. Sambil melakukan pengamatan, peneliti ikut melakukan apa yang dikerjakan oleh sumber data, dan ikut merasakan suka dukanya.

Wawancara

Menurut Sugiyono (2013:72) "Wawancara digunakan sebagai teknik pengumpulan data apabila peneliti ingin melakukan studi pendahuluan untuk menemukan suatu permasalahan yang harus diteliti serta apabila peneliti ingin mengetahui hal-hal dari responden lebih mendalam". Wawancara dilakukan dengan responden untuk mengetahui dan mendapatkan data mengenai peranan Karang Taruna dalam kegiatan pembanguan di desa Metun Sajau.

Dokumentasi

Menurut Sugiyono (2010:329) "Menyatakan dokumen merupakan catatan peristiwa yang sudah berlalu. Dokumen bisa berbentuk tulisan, gambar atau karyakarya monumental dari seseorang". Dokumentasi yang dibutuhkan dalam penelitian ini berupa dokumen terkait dengan peranan Karang Taruna Bunga Bakung dalam kegiatan pembangunan di desa Metun Sajau.

Dari pendapat kedua ahli diatas penulis menyimpulkan dokumentasi adalah pengumpulan data yang dilakukan untuk mendapatkan data sekunder berupa dokumen atau arsip, laporan tahunan, dan karya ilmiah yang relevan dengan penelitian ini.

\section{Teknik Analisis Data}

Analisis data yang digunakan adalah analisis data model alir melalui tahapantahapan sebagai berikut:

Adapun penjelasan dari gambar model interaktif yang dikembangkan Miles dan Huberman (1984) dalam Sugiyono (2013: 91) adalah sebagai berikut:

\section{Pengumpulan Data}

Pengumpulan data adalah data pertama atau data mentah dikumpulkan dalam suatu penelitian.

\section{Reduksi Data}

Reduksi data dimaksudkan sebagai proses pemilihan, pemusatan perhatian pada penyederhanaan, pengabstrakan dan transformasi data mentah yang muncul dari catatan yang tertulis dilapangan.

3. Penyajian Data (Data Display)

Display data dimaksudkan sebagai sekumpulan informasi tersusun yang memberikan kemungkinan adanya penarikan kesimpulan dan pengambilan tindakan dengan melihat penyajianpenyajian, kita dapat memahami apa yang sedang terjadi.

4. Penarikan Kesimpulan/Verifikasi

Sedang verifikasi merupakan kegiatan pemikiran kembali yang melintas dalam pemikiran penganalisis selama peneliti mencatat atau suatu tinjauan ulang pada catatan-catatan lapangan atau peninjauan kembali serta tukar pikiran antara teman sejawat untuk mengembangkan "kesempatan inter subjektif" dengan kata lain makna yang muncul dari data harus diuji kebenarannya.

\section{HASIL DAN PEMBAHASAN}

\section{A. Sejarah Desa}

Desa Sajau berawal dari salah satu daerah di wilyah Kecamatan Tanjung Palas yang mana Desa Sajau merupakan Desa Induk dan mempunyai 3 Dusun pada waktu itu yaitu Sajau Hilir, Pura Sajau dan Binai. Desa Sajau pada saat itu di pimpin oleh Bapak H. Amir. Pada tahun 1991 pengelolaan desa diserahkan kepada pemerintah daerah dan selanjutnya dilakukan pemilihan kepala Desa yang 
pertama dan terpilih Bapak Gung Ajang. Pada masa pemerintahan kepala Desa pertama ini kegiatan Desa Sajau banyak digunakan untuk menata Administrasi Desa, kelembagaan kelompok RT/RW walaupun masih bersifat sederhana, dan penataan kelompok-kelompok pertanian yang lain. Pada saat itu kegiatan kelompok masyarakat ini banyak bekerja pada sektor pertanian dan pada kelompok kecil pada sektor perkebunan.

B. Peranan Pemuda Karang Taruna

Bunga Bakung Dalam Pembangunan

Di Desa Metun Sajau

Peran Pemuda Karang Taruna Bunga

Bakung dalam pembangunan di Desa Metun Sajau merupakan wujud nyata keterlibatan dalam usaha membangun desa baik secara fisik maupun nonfisik. Pembangunan di desa Metun Sajau sangat penting untuk meningkatkan kesejahteraan masyarakat dan mewujudkan perubahanperubahan atau perkembangan desa menuju kearah yang lebih baik.

Peran Karang Taruna dalam pembangunan di desa Metun Sajau.

1. Pembangunan Sarana Jalan

Salah satu peran Pemuda Karang Taruna Bunga Bakung di desa Metun sajau yaitu berpartisipasi dalam meningkatkan perekonomian masyarakat desa. Upaya ini dilakukan dengan cara keterlibatan dalam pembuatan jalan agar memperlancar mobilitas atau pergerakan masyarakat. Sarana trasportasi jalan berperan sebagai pendukung kegiatan ekonomi masyarakat dalam distribusi hasil pertanian.
Kondisi jalan masih sangat memprihatinkan terutana jalan petani oleh karena itu, pembangunan sarana jalan di Desa Metun Sajau sangat diperlukan agar masyarakat lebih mudah menjangkau pertanian. Dalam pembangunan jalan tersebut, Karang Taruna Desa Metun Sajau sudah terlibat mengikuti kerja bakti untuk pembuatan jalan dan kerja bakti untuk memperbaiki sarana jalan yang sudah mulai rusak.

Peran Karang Taruna mengadakan kegiatan kerja bakti dan penataan lingkungan. Misalnya: mengadakan jumat bersih bersama warga dan pemuda lainnya, mengadakan bersih masjid setiap hari minggu bersama rismawan dan rismawati desa setempat (Dini Destinasari, Adelina Hasyim, Yunisca Nurmalisa, 2016).

Pendapat di atas sesuai dengan hasil penelitian bahwa peran Karang Taruna Desa Metun Sajau dalam pembangunan di desa sangat besar sekali dimana mereka terlibat dalam pembuatan jalan dan merenovasi jembatan yang sudah rusak. Peran Karang Taruna Desa Metun Sajau dalam pembangunan tersebut merupakan bagian dari program kerja yang harus direalisasikan.

2. Pembangunan Rumah Adat Pembangunan sarana Balai Desa dimaksudkan untuk memenuhi kebutuhan masyarakat Desa Metun Sajau dalam melaksanakan kegiatan yang dilakukan 
oleh masyarakat desa. Tentunya sebuah desa harus mempunyai sebuah tempat atau gedung yang dapat digunakan apabila ada acara-acara yang diadakan di desa itu sendiri. Balai Desa adalah gedung yang dapat menampung seluruh masyarakat desa Metun Sajau apabila ada kegiatan atau acara besar yang dilakukan. Dimana balai desa tersebut berfungsi sebagai tempat diadakan suatu kegiatan-kegiatan tertentu misalnya tempat pertemuan, kesenian, dan pernikahan adat yang dilakukan dibalai desa.

Pembangunan dan perbaikan Balai Desa Metun Sajau selalu melibatkan Karang Taruna Bunga Bakung dalam proses pengerjaan, karena itu merupakan program kerja Karang Taruna yang harus berperan dalam pembangunan desa. Karang Taruna selalu berperan dalam pembanguan Balai Adat, baik saat mengerjakan ataupun saat menyusun rencana perubahan ataupun pembangunan Balai Desa.

3. Pembangunan Tribun Lapangan

Keterlibatan Karang Taruna Bunga

Bakung dalam pembangunan dapat dilihat saat pembangunan tribun olehraga, para pemuda/Karang Taruna terlibat langsung dalam kegiatan pembangunan.

Menurut Syukur (2008:27) generasi muda atau pemuda adalah penduduk yang berusia 15-35 tahun, yaitu mereka yang di idealkan sebagai sosok yang penuh energi, semangat, dan kreativitas untuk menciptakan semangat pembaharuan.

Berdasarkan teori tersebut, peran Karang Taruna dalam pembangunan di Desa Metun Sajau tentu menjadi agen perubahan dengan menciptakan sarana dan prasarana untuk kebutuhan masyarakat.

Sarana olahraga merupakan tanggung jawab semua masyarakat desa Metun sajau, terlebih kapada Karang Taruna Bunga Bakung harus mampu membangun dan memelihara sarana tersebut. Tanggung jawab yang diamanakan kepada Karang Taruna Bunga Bakung merupakan suatu kewajiban yang harus ditangani supaya desa Metun Sajau betul-betul terpelihara sarana pembanguan yang ada.

4. Pembangunan Sarana olahraga

Pembangunan sarana olahraga saat ini masih tetap dilaksanakan oleh Karang Taruna Bunga Bakung, salah satu pembangunan yang dikerjakan yaitu pembangunan gedung badminton (bola Tangkis) masih dalam proses pengerjaan. Peran Karang Taruna Bunga Bakung dalam pembangunan tersebut sebagai pengawas pelaksanaan pembangunan. Pembangunan gedung badminton merupakan program kerja Karang Taruna Bunga Bakung untuk mendapatkan bangunan badminton yang lebih besar dan lebih baik sehingga Karang Taruna Bunga Bakung melakukan kerja sama dengan pihak perusahaan. 
Tabrani $\quad(2002: 183) \quad$ juga mengungkapkan bahwa olahraga khususnya adalah penting untuk menggiatkan kreativitas. Dari hasil penelitian yang diperoleh, diharapkan dengan adanya fasilitas olahraga yang dimiliki oleh Karang Taruna/Desa Metun Sajau dapat meningkatkan pembangunan di bidang olah raga.

Peran Karang Taruna Bunga Bakung dalam pembangunan di desa Metun Sajau dapat dilihat dari kegiatan mereka yang sudah membangun lapangan bola voli, lapangan futsal, lapangan sepakbola dan lapangan bola tangkis. Semua pembangunan tersebut dikerjakan oleh Karang TarunaBunga Bakung untuk mempasilitasi masyarakat berolahraga.

Karang Taruna Bunga Bakung desa Metun Sajau berperan dalam pembangunan non fisik yaitu:

1. Menyumbangkan Pendapat Keterlibatan Karang Taruna Bunga BakungDesa Metun Sajau dalam menyampaikan pendapat, ide atau gagasan merupakan salah satu peran dalam membangun desa. Ide dan gagasan Karang Taruna Bunga Bakung sangat dibutuh oleh pemimpin yang menjalankan tugas kepemimpinan berasaskan demokrasi. Dari gagasan tersebutlah akan lahir sebuah kebijakan yang diperuntukan untuk kepentingan masyarakat Desa Metun Sajau.
Rapat Desa Metun Sajau selalu diadakan untuk membahas tentang rencana-rencana pembangunan desa misalnya pembangunan sarana olahraga, pembuatan jalan, pembuatan paret, air bersi dan lainnya. Dalam pertemuan tersebut, Karang Taruna Bunga Bakung terlibat untuk menyumbangkan pendapat, ide atau gagasan agar pembangunan di desa benar-benar dapat bermanfaat bagi masyarakat.

2. Keamanan dan Ketertiban Peran Karang Taruna Bunga Bakung dalam keamanan dan keterlibatan sudah baik, mereka turut menjaga keamanan dan kenyaman dalam bermasyarakat. Pada saat hari raya, Karang Taruna mengambil bagian untuk menjaga keamanan desa.

3. Pelestarian Kesenian Daerah

Salah satu peran Karang Taruna yaitu membangun dan melestarikan kesenian daerah yang dimiliki oleh masyarakat desa Metun Sajau. Mengingat bahwa Desa Metun Sajau merupakan desa wisata maka kami merasa bertanggung jawab untuk melestarikan dan meningkatkan kesenian desa.

Seperti yang disampaikan oleh Ainun Ramadhan (2015) bahwa Karang taruna merupakan sebuah wadah pemuda yang sangat tepat sebagai sarana pembangunan dan pelestarian kearifan lokal yang dimiliki oleh sebuah daerah. 
Dalam meningkatkan pembanguan sesuai dengan kearifan local, Karang Taruna Bunga Bakung sangat antusias, mereka terlibat dalam pengurusan kesenian Desa Metun Sajau, dan ada juga sebagian pemuda yang membentuk Sanggar Seni dengan harapan kesenian yang ada di desa Metun Sajau tetap terjaga dan dapat ditingkatkan.

B. Kendala-kendala yang Dihadapi

Karang Taruna Bunga Bakung dalam

Pembangunan Di Desa Metun Sajau

Kendala yang dihadapi dalam rangka mengikuti kegiatan pembangunan di desa Metun Sajau disebabkan karenaketuan Karang Taruna kurang memberikan informasi dan melakukan koordinasi antara sesama anggota dan dengan masyarakat dalam menyelenggarakan program kerja.

Kendala yang dihadapi oleh pengurus Karang Taruna Bunga Bakung dalam melaksanakan kegiatan pembangunan di desa Metun Sajau disebabkan karena keterbatasan dana, sarana dan prasarana yang digunakan dalam kegiatan pembangunan dan keterbatasan waktu karena masing-masing anggota memiliki pekerjaan, ada yang di pemerintahan (sekolah), ada yang bekerja di swasta (perusahaan).

Kurangnya koordinasi dari pimpinan dan dana yang terbatas mengakibatkan kurangnya sarana dan prasarna Karang Taruna sehingga berdampaknya kepada motivasi dari pengurus karang Taruna itu sendiri.

Kendala yang dihadapi oleh Karang Taruna dalam menjalankan peran organisasi di desa Metun Sajau disebabkan kurangnya koordinasi. Hal itu didukung dengan pendapat Rivai dan Mulyadi (2011, hlm. 130-131) dalam (Ainun Ramadhan, 2011) bahwa organisasi hubungan antara pemimpin dan bawahan idealnya seperti ini :

1) Pemimpin memegang peranan penting dalam berkomunikasi, karena pemimpin berhadapan dengan bermacam pribadi yang berbeda watak maupun latar belakangnya, maka pemimpin harus menyadari perbedaan watak dan latak belakang bawahannya.

2) Komunikasi yang dilakukan pemimpin dapat berbentuk instruksi atau perintah, saran, bimbingan, petunjuk, nasihat maupun kritik yang sifatnya membangun.

Kendala ektern tersebut berupa kurangnya kesadaran masyarakat desa akan adanya peran dan fungsi organisasi Karang Taruna yang membantu masyarakat desa dalam kegiatan pembangunan, sehingga peran Karang Taruna kurang dimanfaatkan oleh masyarakat desa, serta Karang TarunaBunga Bakung kurang mendapatkan perhatian dari pemerintahan desa yang seharusnya menjadi pasilitator 
dalam pelaksanaan program kerja Karang Taruna.

\section{PETUTUP}

Hasil penelitian menunjukan peran pemuda Karang Taruna Bunga Bakung dalam pembangunan di Desa Metun Sajau dapat dilihat dari pembangunan fisik diantaranya pembangunan sarana jalan, pembangunan rumah adat, pembangunan tribun lapangan, dan pembangunan sarana olahraga. Peran dalam pembangunan non fisik diantaranya menyampaikan pendapat saat rapat desa, menjaga keamanan dan ketertiban, dan pelestarian kesenian daerah.

Kendala-kendala yang dihadapi Karang Taruna Bunga Bakung dalam pembangunan di Desa Metun Sajau yaitu keterbatasan dana, kurangnya sarana dan prasarana, kurangnya komunikasi dan koordinasi dari pimpinan, sibuk karena pekerjaan, kurang tegas pimpinan organisasi Karang Taruna, kurangnya kesadaran masyarakat desa peran dan fungsi Karang Taruna, dan kurangnya perhatian pemerintah desa.

\section{DAFTAR PUSTAKA}

Destinasari, Dini; Hasyim, Adelina; Nurmalisa, Yunisca. 2016. Peranan Karang Taruna dalam Meningkatkan kepedulian sosial Pemuda Kelurahan Margodadi. Jurnal Kultur Demokrasi. Vol 4, No 6 (2016).

Efendi, Bacthiar. 2002. Pembangunan Daerah Otonom Berkeadilan
(Cetakan Pertama). PT. Uhaindo dan Offset.

Kawalod, Farra Aprilia; Rorong, Arie; Londa, Verry Y. 2015. Peranan Organisasi Karang Taruna Dalam Pemberdayaan Masyarakat Desa (Suatu Studi Di Desa Tewasen, Desa Pondos, Desa Elusan, Desa Wakan Kecamatan Amurang Barat Kabupaten Minahasa Selatan). Jurnal Administrasi Publik. Vol 3, No 031 (2015)

Khairuddin. 2000. Pembangunan Masyarakat Tinjauan Aspek Sosiologi, Ekonomi, dan Perencanaan, Liberty Yogyakarta.

Kurniasari, Dewi. 2013. Peranan Organisasi Karang Taruna Dalam Mengembangkan Kreativitas Generasi Muda Di Desa Ngembalrej. Unnes Civic Education Journal. 2016. Vol 2 No 2. ISSN 2252-7133.

Kurniawan, Fauzi. 2016. Beberapa Teori TentangPembangunan. post 29-032016.

Lendriyono, Fauzik. 2007. Pemikiran tentang Pembangunan Kesejahteraan Sosial, Universitas Muhamadiyah Malang.

Ramadhan, Ainun. 2011. Disfungsional Peran Karang Taruna Dalam pelestarian Kearifan Lokal di Kampung. Jurnal Pendidikan Sosiologi. Vol 1, No 1 (2011)

Soejanto, Agoes. 2005. Psikologi Perkembangan. PT Rineka Cipta, Jakarta.

Soekanto, Soerjono. 2007. Sosiologi Suatu Pengantar. Jakarta: Grafindo Persada. Subandi. 2011. "Ekonomi Pembangunan (cetakan kesatu)"..Bandung: Alfabeta

Sugiyono. 2010. Metode Penelitian Kualitatif dan $R \& D$. Bandung: Alfabeta.

Sugiyono. 2013. Metode Penelitian Kualitatif dan $R \& D$. Bandung: Alfabeta.

Tabrani, Primadi. 2002. Proses Kreasi, Apresiasi, Belajar. Bandung: Penerbit ITB 